\title{
Factor Analysis of Training, Knowledge, Supervision, and Unsafe Actions on Occupational Accidents at PT X
}

\author{
Analisis Faktor Pelatihan, Pengetahuan, Pengawasan dan Tindakan Tidak \\ Aman terhadap Kecelakaan Kerja di PT X
}

\author{
Noor Intan Ramadhani \\ PT. Ritel Global Solusi \\ Jalan Panglima Sudirman No. 27 , Dapur Barat, Sidokumpul \\ Lamongan, East Java, Indonesia 62213
}

\begin{abstract}
Introduction: Industrial accidents are accidents occurring in the workplace, especially in the industrial environment. According to the data, the occupational accidents at PT X in RKC (raw mill, kiln, cooler) Operational Section of Slag Production are still found annually. From 2015 to 2017, there had been nine occupational accidents recorded. There was one occupational accident in 2015, five occurrences in 2016, and three occurrences in 2017. This study aimed to analyze the factors of supervision, training, knowledge, and unsafe actions that can lead to occupational accidents suffered by the workers in RKC Operational Section of Slag Production at PT X. Methods: This study was a crosssectional study with a population of 19 people by implementing the descriptive test analysis to describe the percentage of each observed dependent variable. Results: This study revealed that $78.9 \%$ of the workers claimed that the supervision was good, $73.7 \%$ agreed that the training was good, 57.9\% agreed that they had good knowledge, and $52.6 \%$ claimed to conduct unsafe actions in moderate level. Conclusion: The factors of supervision, training, and knowledge were influential to the occurrence of occupational accidents, yet they remained within the tolerable level since almost all workers performed in the good category in those categories. On the other hand, unsafe actions had a considerable influence on the occurrence of occupational safety and health since the majority of the workers performed unsafe actions moderately.
\end{abstract}

Keywords: factor analysis, occupational accidents, unsafe actions

\begin{abstract}
ABSTRAK
Pendahuluan: Kecelakaan industri adalah kejadian kecelakaan yang terjadi di tempat kerja, khususnya di lingkungan industri. Data kecelakaan kerja di PT X, pekerjaan dibagian Operasi RKC (Raw mill, kiln, coller) Produksi Terak masih terdapat kasus kecelakaan kerja yang terjadi tiap tahunnya. Tahun 2015 hingga 2017 terjadi kecelakaan kerja sebanyak 9 kasus kecelakaan kerja tercatat. Tahun 2015 terjadi satu kasus kecelakaan kerja, tahun 2016 sebanyak lima kasus dan tahun 2017 sebanyak 3 kasus. Penelitian ini bertujuan untuk menganalisis faktor pengawasan, pelatihan, pengetahuan dan tindakan tidak aman yang dapat menyebabkan kecelakaan kerja pada pekerja di bagian Operasi RKC Produksi Terak di PT X. Metode: Jenis penelitian cross sectional dengan total populasi 19 orang dan menggunakan analisis Uji deskriptif yang akan menggambarkan besaran persentase tiap variabel dependen yang diteliti. Hasil: Penelitian menunjukkan bahwa pengawasan sebesar 78.9\% tergolong kategori baik, pelatihan sebesar $73.7 \%$ tergolong kategori baik, pengetahuan sebesar $57.9 \%$ tergolong kategori baik dan tindakan tidak aman sebesar $52.6 \%$ tergolong kategori sedang. Simpulan: Faktor pengawasan, pelatihan dan pengetahuan memiliki pengaruh terhadap kejadian kecelakaan kerja tetapi masih dapat ditolelir karena sebagian besar pekerja termasuk dalam kategori yang baik sedangkan tindakan tidak aman memiliki pengaruh yang cukup besar terhadap kejadian kecelakaan kerja karena sebagian besar pekerja melakukan tindakan tidak aman.
\end{abstract}

Kata kunci: analisis faktor, kecelakaan kerja, tindakan tidak aman

\section{Corresponding Author:}

Noor Intan Ramadhani

Email: nintan81@yahoo.com

(C2019 IJOSH All right reserved. Open access under CC BY NC-SA license doi: 10.20473/ijosh.v8i2.2019. 178-186

Received August 03, 2017, received in revised form February 20, 2019, Accepted July 18, 2019, Published: August 2019 


\section{INTRODUCTION}

The industrialization development in this globalization era has caused an increase of infrastructure developments, such as the construction of office buildings, road expansion, building renovations, etc. In order to generate a decent and qualified development, the good quality and guaranteed quantity of raw materials are extremely required. The workforce is one of the most important resource components in the production process of certain industries. The skills and performance of the workforce are becoming more essential for them to be noticed by the industry. According to Lestari and Sriathi (2013), a good company supposedly has good human resources. This can be identified by physical, mental, and psychological health as well as the work performance and the workers' productivity.

Indonesia is one of the countries with a high number of occupational accidents. Generally, all kinds of occupations that involve workforces in its process has different risks, depending on the occupation itself. Referring to the data obtained from Burhani (2010) there were 88,492 cases that resulted to 1,970 workforces died, 4,023 workforces suffered from functional disabilities, 2.534 workforces suffered from permanent anatomical disabilities, and 79.986 workforces got recovered. Thus, it can be perceived that the number of occupational accidents in Indonesia is still high.

Denoting Ministry of Health Republic of Indonesia (2014) according to the data obtained by International Labour Organization (ILO) in 2013, every workforce in the world dies every 15 seconds caused by occupational accidents, and 160 workforces suffer from occupational illnesses. In the previous year of 2012, ILO identified that there were two million cases of death every year caused by occupational accidents and occupational illnesses.

Furthermore, referring to the data compiled by the National Social Security (BPJS), until the end of 2015, there had been 105,182 cases of occupational accidents. In the meantime, the severe cases of occupational accidents resulting in death were noted to reach 2,375 cases from the total number of occupational accidents. The Director-General of Labour Inspection and Occupational Safety and Health, the Ministry of Labour, Muji Handaya, declared that the number of occupational accidents increases annually.

In addition, the National Social Security recorded that, nationally, they had dealt with 105,383 cases of occupational accidents until the end of 2014. From the figure, it was found out that the case of functional disabilities reached 3,618 cases, partial disabilities amounted to 2,616 cases, total disabilities recorded 43 cases, and death cases reaching 2,375 cases. Additionally, until March 2015, the National Social Security had handled 38 cases of Working Accident Protection-Return to Work (JKK-RTW).

Industrial accidents are the accidents occurring in a workplace, particularly in the industrial environment and happen when the workers are doing their works. Occupational accidents are unwanted and unexpected incidents that can result in physical, mental, psychological, and material losses. Occupational accidents can be caused by both internal and external factors. The internal factors are the factors that arise from within the workers themselves, while the external factors are the factors that can arise due to the influence of the working environment. Occupational accidents are generally caused by 2 (two) main things, namely unsafe actions and unsafe conditions. Referring to the Government Regulation (2012) 80\% of occupational accidents in Indonesia are reportedly caused by unsafe actions that can harm the workers themselves or everyone else.

Based on the President of the Republic of Indonesia (1970), occupational accidents are the unexpected and unwanted incidents, which disrupt the arranged activity process and cause the loss in forms of death tolls or material losses. According to the President of the Republic of Indonesia (1992) Paragraph 1 Article 6, occupational accidents are the accidents related to work, including diseases caused by the work, and accidents that occur since workers depart from 
home to the workplace until they go home from the workplace.

One of the theories concerning the trigger of occupational accidents is the Swiss Cheese Model proposed by James Reason (1990), as cited by (Abiszah, 2014). This model portrays Swiss cheese with holes, representing the mistakes or negligence that potentially cause dangers and accidents. The negligence is illustrated by an exploding bomb, exposed to walls of cheese. Parts of the explosion is held in the cheese layers, and other parts go through the cheese holes. If the explosion passes the cheese walls by going through the holes, it can be assured that accidents are likely to happen. On the other hand, if the explosion cannot pass through the cheese walls, the mistakes or negligence are believed to be tolerable.

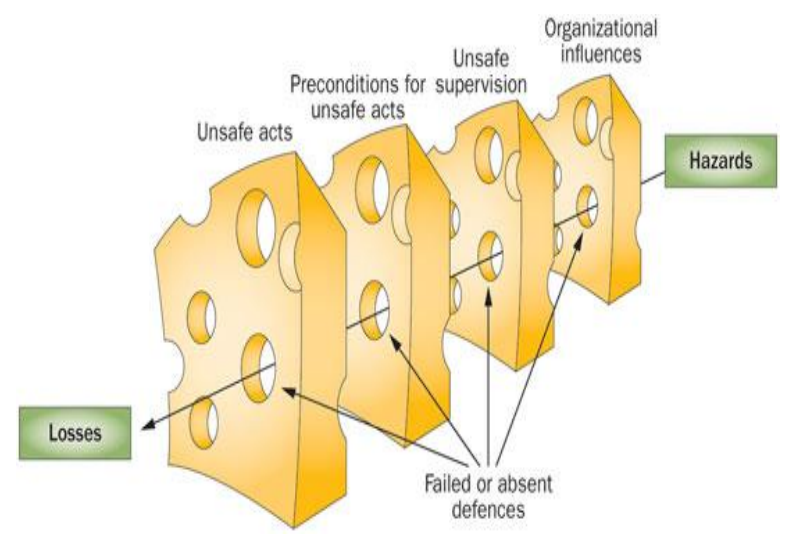

Figure 1. The Swiss Cheese Model

The cause of occupational accidents in terms of human negligence is influenced by four factors. The first factor is the organizational influence, which declares that a good state of an organization can affect the working performance of the workers. The second factor is the unsafe supervision, which means that the supervision of the condition and unsafe actions are not properly executed. The third factor is the preconditions for unsafe actions, which refers to the situation that is likely to initiate unwanted incidents. The last factor is the unsafe action, namely the action that does not comply with the procedures or the SOP established by the company.
Unsafe actions or behaviors are the actions or behaviors that can initiate the occurrence of accidents or incidents. On the other hand, safe actions are the actions that are not going to cause any accident or incident Bird, Frank and Germain (1990). According to Pratiwi and Hidayat (2014), unsafe actions is a kind of human failure in following the correct conditions and working procedures that can cause occupational accidents.

In this globalization era, the production processes apply sophisticated technologies. Nonetheless, human force is still required as the operators, which makes the human factor as the dominant factor when it comes to unsafe actions. Riyadina (2007) found some research results revealing that human factor plays an important role in the emergence of occupational accidents. The results claimed that $80 \%-85 \%$ of occupational accidents were caused by negligence or human error.

In addition, the research conducted by Pratiwi and Hidayat (2013) suggested that the majority of the 74 respondents in their research performed unsafe actions. In the explanation, 13 respondents or $17.6 \%$ performed well in safe actions, 26 respondents $(35.1 \%)$ performed low in the same category, 24 respondents (32.4\%) performed moderately in the unsafe actions, and 11 respondents (14.9\%) performed high level of unsafe actions. Thus, these results proved that almost all workers were discovered to keep conducting unsafe actions.

PT $\mathrm{X}$ is a company engaged in the cement industry. PT $\mathrm{X}$ consists of several sections, i.e., one of those is RKC (Raw mill, Kiln, Cooler) Operational Section of Slag Production. This section is included in the production process, in which the raw mill pulverizes the raw material and then burned in kiln in the temperature of $8,00^{\circ} \mathrm{C}-$ $1,200^{\circ} \mathrm{C}$. The result of the kiln process is called slag.

Referring to the data on occupational accidents at PT X, in RKC (Raw mill, kiln, cooler) Operational Section of Slag Production, the occupational accidents still occur annually. Moreover, according to the data, the number of recorded occupational accidents in RKC (Raw 
mill, kiln, cooler) Operational Section had increased from 2015 to 2017. In the explanation, in 2015, there was one occupational accident, namely hot material exposure that resulted in skin burns. In 2016, there were five cases of occupational accidents recorded, such as being exposed to the hot material, mired, wedged, and fire burn. In 2017, three cases of occupational accidents were identified, including being exposed to pressured air and hot dust. Thus, it can be stated that in RKC (Raw Mill, Kiln, Cooler) Operational Section, there was an occupational accident recorded annually. These could happen due to the unsafe actions carried out by the workers or the lack of supervision performed by the management and training provided for the workers. In this section, the cement production process in which the raw mill pulverizes the raw material and then burned in a combustion engine with a temperature of $800^{\circ} \mathrm{C}-1,200^{\circ} \mathrm{C}$. The product of the combustion is then labeled as slag.

This study aims to analyze the factors of supervision, training, knowledge, and unsafe actions that can initiate the emergence of occupational accidents to the workers in the RKC Operational Section of Slag Production at PT X. Therefore, the company can carry out some preventions of the occurrence of occupational accidents in the company to decrease the number of occupational accidents.

\section{METHODS}

Based on the data analysis, this study was a descriptive study. This study depicted and analyzed the correlation between supervision, training, knowledge, and unsafe actions and the occupational accidents of the workers in RKC (Raw mill, kiln, cooler) Section at PT X.

In addition, this study was an observational study, where the data collection was conducted by observing and conducting an interview with the workers in RKC (Raw mill, kiln, cooler) Section. Based on the location where this study took place, it is considered as field research. Meanwhile, from the type, this study is a cross-sectional study since it was conducted in a certain period of time.
The population of this study was all 19 workers in RKC (Raw mill, kiln, cooler) Operation Section in PT X. The data collection technique and the applied instrument resulted in primary and secondary data. The primary data was obtained by interviewing with the workers by spreading questionnaire and observing the workers of RKC Operational Section of PT X when doing their works based on the observation sheets. Furthermore, the secondary data was gathered from PT X, including the emergence of occupational accidents in RKC (Raw mill, kiln, cooler) Operational Section.

In this study, occupational accidents served as the dependent variable, while supervision, knowledge, training, and unsafe actions functioned as the independent variables. Additionally, this study implemented a descriptive test analysis that depicted each analyzed variable percentage.

\section{RESULTS}

\section{Company General Description}

PT X is a company operating in the field of cement production. The company was first inaugurated by the President of the Republic of Indonesia with the installed capacity of 250,000 tons of cement annually. In 2014, the installed capacity reached 31.8 million tons.

In realizing the effectiveness and the efficiency of the governance, the company has implemented the integrated management that refers to the principles of good corporate governance, namely Management System X, including Quality Management System (ISO 9001), Environmental Management System (ISO 14001), Occupational Safety and Health Management System (SMK3-OHSAS 18001), Testing Laboratory Management System (ISO/IEC 17025), Risk Management System (ISO 31000), and Mining Safety Management System, as well as the improvement programs through the implementation of Innovation Management.

The implementation of Management System $\mathrm{X}$ is expected to increase the added value 
for the shareholders in particular and other stakeholders in general.

In the Management System $X$, the integrated audit to guarantee the consistent and consequent implementation of the management system is also carried out. To ensure the continuous improvement, PT $\mathrm{X}$ realizes several policies to apply the Innovation Management System (IMS), namely innovative activities, quality control groups, the 5R program (ringkas (concise), rapi (neat), resik (clean), rawat (care) and rajin (diligent)), suggestion system, and total productive maintenance. The total productive maintenance has been upgraded by the implementation of Reliability Centred Maintenance (RCM) and quality control projects to achieve the international level of the operational management in accordance with the vision of PT $\mathrm{X}$.

\section{Supervision Distribution}

The distribution of the respondents based on supervision is shown in Table 1.

Table 1. The Distribution of the Respondents Based on the Supervision Given to the Respondents in PT X

\begin{tabular}{lcc}
\hline $\begin{array}{l}\text { Supervision } \\
\text { Category }\end{array}$ & Frequency & $\begin{array}{c}\text { Percentage } \\
(\boldsymbol{\%})\end{array}$ \\
\hline Good & 15 & 78.9 \\
Moderate & 4 & 21.1 \\
\hline Total & 19 & 100.0 \\
\hline
\end{tabular}

From Table 1, it can be identified that from 19 respondents, 15 respondents $(78.9 \%)$ stated that the supervision provided by the company was good. However, the other four respondents (21.1\%) agreed that the supervision provided by the company was moderate.

\section{Training Distribution}

From Table 2, it can be perceived that from 19 respondents, 14 of them $(73.7 \%)$ confirmed that the training given by the company was already good. In addition, 4 respondents $(21.1 \%)$ claimed that the training provided by the company was moderate, followed by one respondent $(5.3 \%)$ who claimed that the training given was poor.

Table 2. The Distribution of the Respondents based on the Training Given to the Respondents in PT X

\begin{tabular}{lcc}
\hline $\begin{array}{l}\text { Training } \\
\text { Category }\end{array}$ & Frequency & $\begin{array}{c}\text { Percentage } \\
(\boldsymbol{\%})\end{array}$ \\
\hline Good & 14 & 73.7 \\
Moderate & 4 & 21.1 \\
Poor & 1 & 5.3 \\
\hline Total & 19 & 100.0 \\
\hline
\end{tabular}

\section{Knowledge Distribution}

The distribution of the respondents based on the knowledge is presented in Table 3.

Table 3. The Distribution of the Respondents based on the Knowledge Given to the Respondents in PT X

\begin{tabular}{lcc}
\hline $\begin{array}{l}\text { Knowledge } \\
\text { Category }\end{array}$ & Frequency & $\begin{array}{c}\text { Percentage } \\
(\%)\end{array}$ \\
\hline Good & 11 & 57.9 \\
Moderate & 8 & 42.1 \\
\hline Total & 19 & 100.0 \\
\hline
\end{tabular}

From Table 3, it can be distinguished that from 19 respondents, there were 11 respondents (57.9\%) whose knowledge was already good. Meanwhile, the other eight respondents (42.1\%) was noticed to have moderate knowledge.

\section{Unsafe Actions Distribution}

Table 4. The Distribution of the Respondents based on the Unsafe Actions Conducted by the Respondents in PT X

\begin{tabular}{lcc}
\hline $\begin{array}{l}\text { Unsafe Actions } \\
\text { Category }\end{array}$ & Frequency & $\begin{array}{c}\text { Percentage } \\
(\boldsymbol{\%})\end{array}$ \\
\hline Low & 9 & 47.4 \\
Moderate & 10 & 52.6 \\
\hline Total & 19 & 100.0 \\
\hline
\end{tabular}

Based on Table 4, it can be identified that from 19 respondents, 9 of them $(47.4 \%)$ carried 
out unsafe actions categorized as low. The other ten respondents $(52.6 \%)$ were discovered to perform unsafe actions in the moderate category.

\section{Occupational Accidents Distribution}

The data regarding the occupational accidents emerged to the workers of RKC (Raw mill, Kiln, Cooler) Section at PT X from 20152017 is presented in Table 5. According to Table 5, it was found that from 2015 until 2017, there had been nine cases of occupational accidents suffered by the workers at PT X. Those accidents were reported and identified cases. From 2015 until 2016, the occupational accidents had experienced a significant increase, while from 2016 until 2017, the occupational accidents experience decreased.

\section{DISCUSSION}

\section{Factor Analysis between Training and Occupational Accidents}

Training is an endeavor to improve and or to develop working performances of a job that becomes the workers' responsibility. By joining the training, the workers are expected to become more skilled in doing their jobs, so that they can be more productive and reduce the bad or negative impacts due to the lack knowledge of the workers.

From the research concerning the training at PT X, the results of the questionnaire revealed that $73.7 \%$ of the workers agreed that the training provided by the company was already good. However, the other four respondents (21.1\%) stated that the training given was moderate, and the remaining one respondent $(5.3 \%)$ claimed that the training provided by the company was poor.

According to the data on the occupational accidents occurred at PT X during 2015-2017, it was discovered that there was a correlation between the training and the emerging occupational accidents. Most of the accidents were caused by the exposure of hot dust from the cement resulting in skin burns. Therefore, the training on how to operate the equipment emitting hot dust to avoid the exposure of hot dust and how to watch the wind direction so that the workers do not stand in the way of the hot dust flow.
From 19 respondents who participated in fulfilling the questionnaire, it was noticed that there were statements that agreed if the training provided by the company had not yet accomplished a good category. This situation can be one of the triggers of the emergence of occupational accidents in the company. However, it was not the main cause, since the majority of the workers claimed that the training provided by the company was already good.

According to Kurniawati (2014), one of the advantages of organizing training is to reduce and to eliminate the possibility of accidents because, with good training, the workers can identify the hazards in their works and be familiar with the actions they should anticipate the hazards. On the other hand, the workers who never join any work training are more likely to carry out unsafe actions in their work.

Thus, even though the training is not the main cause of occupational accidents, it is still indispensable to be given to the workers as a measure to increase the awareness and the workers' ability in safe working, whether it is general or specific training, in accordance with the type of work.

\section{Factor Analysis between Knowledge and Occupational Accidents}

Referring to Raharjo (2013) knowledge is crucial to shaping somebody's behavior. In order to change to new behavior, one needs a long time and a complex process. Almost all of the human's knowledge is acquired through senses, especially eyes and ears. The workers are capable of identifying hazards by those senses. Therefore, workers with good knowledge are believed to be able to prevent the emergence of occupational accidents both for themselves and for other people.

From the research on the knowledge of Occupational Safety and Health at PT X, the questionnaire results revealed that $57.9 \%$ of the respondents already had good knowledge. Nonetheless, $42.1 \%$ of the respondents had only moderate knowledge. The provision of workers' knowledge was still at a moderate level, and this situation could be one of the causes of the 
emergence of occupational accidents in the company. Then again, this was not the main cause since more than half of the respondents had a good level of knowledge.
According to Pratama (2015), workers with good knowledge will likely to prevent the occurrence of occupational accidents to both themselves and other people.

Table 5. The Distribution of the Occupational Accidents in RKC (Raw mill, kiln, cooler) at PT X

\begin{tabular}{|c|c|c|c|}
\hline Occupational Accident & Cause & Accident Loss & Location \\
\hline \multicolumn{4}{|l|}{2015} \\
\hline Exposed to hot materials & $\begin{array}{l}\text { Feet are exposed to hot dust } \\
\text { materials when opening the main } \\
\text { hole }\end{array}$ & Skin burns 5\%, stadium 2 . & Raw Mill \\
\hline \multicolumn{4}{|l|}{2016} \\
\hline Exposed to hot materials & $\begin{array}{l}\text { The back is exposed to hot dust } \\
\text { materials when tidying up the } \\
\text { working equipment, water pipe, } \\
\text { after completing the cooling } \\
\text { process. }\end{array}$ & $\begin{array}{l}\text { Skin burns on the back of both } \\
\text { hands, on the back of the neck, and } \\
\text { right knee. }\end{array}$ & Preheater \\
\hline Mired & $\begin{array}{l}\text { Mired to the holed floor when } \\
\text { doing an inspection. }\end{array}$ & $\begin{array}{l}\text { Bruises on the right leg below the } \\
\text { knee. }\end{array}$ & Raw Mill \\
\hline Wedged & $\begin{array}{l}\text { Wedged by the spinning } \\
\text { equipment when repairing the } \\
\text { Cooler area. }\end{array}$ & $\begin{array}{l}\text { Skin tore on the tip of the left little } \\
\text { and ring fingers. }\end{array}$ & Cooler \\
\hline Skin burns & $\begin{array}{l}\text { The explosion of the panel breaker } \\
\text { in the electricity room when } \\
\text { repairing the equipment and } \\
\text { switching off the power. }\end{array}$ & $\begin{array}{l}\text { Skin burns } 10 \% \text { on the face (grade } \\
2 \mathrm{~A} \text { ) and the right hand (grade 2B). }\end{array}$ & Preheater \\
\hline Skin burns & $\begin{array}{l}\text { The explosion of the panel breaker } \\
\text { in the electricity room when } \\
\text { repairing the equipment and } \\
\text { switching off the power, causing } \\
\text { two victims suffered from skin } \\
\text { burns. }\end{array}$ & $\begin{array}{l}\text { Skin burns } 6 \% \text { on the face (grade } \\
1 \text { ), from the wrist to the fingers, } \\
\text { and the back of the left hand. }\end{array}$ & Preheater \\
\hline \multicolumn{4}{|l|}{2017} \\
\hline Exposed to pressured air & $\begin{array}{l}\text { Shocked and bounced off caused } \\
\text { by bust up drat connection } \\
\text { disposal when installing the drat } \\
\text { connection system. }\end{array}$ & $\begin{array}{l}\text { Blisters on the left hand, back, and } \\
\text { the right hand. }\end{array}$ & Raw Mill \\
\hline Exposed to hot dust & $\begin{array}{l}\text { Exposed to highly concentrated } \\
\text { dust on the } 6^{\text {th }} \text { floor when the } \\
\text { victim was on the way to the } \\
\text { Preheater on the } 6^{\text {th }} \text { floor. The } \\
\text { concentrated dust caused the } \\
\text { victim suffered from irritation. }\end{array}$ & Eye irritation & \\
\hline Exposed to hot dust & $\begin{array}{l}\text { Exposed to highly concentrated } \\
\text { dust on the } 6^{\text {th }} \text { floor when the } \\
\text { victim was on the way to the } \\
\text { Preheater on the } 6^{\text {th }} \text { floor. The } \\
\text { concentrated dust caused the } \\
\text { victim suffered from irritation. }\end{array}$ & Eye irritation & \\
\hline
\end{tabular}




\section{Factor Analysis between Supervision and Occupational Accidents}

Kurniawati (2014) claims that one of the supervisors' roles includes being the main key in influencing the knowledge, attitudes, skills, and habits related to the safety of the workers in a certain area of his/her responsibility. From the research concerning the supervision of the Occupational Safety and Health at PT X, the results from the questionnaire proved that majority of the workers $(78.9 \%)$ claimed that the supervision in the company was already good. Meanwhile, $21.1 \%$ of the workers stated that the supervision was moderate.

Referring to the data on the occurred occupational accidents, most of it emerged due to the lack of caution at work, for examples exposed to hot dust, mired, wedged by the spinning equipment, and so on. Hence, extra supervisions from the Occupational Safety and Health Section to the workers when doing their works are necessary. Even so, almost all of the workers claimed that the supervision done by the company had already been good, although the opinions stating that the supervision was only moderate were still discovered. Due to that reason, although this is not the main cause since more than half of the workers claimed that the supervision was good, this issue was still believed to be one of the causes of the emergence of occupational accidents in the company. Additionally, supervision was not the main or direct cause of the occurrence of occupational accidents.

According to Abiszah (2014), training, supervision, and working procedures are the administrative controls that are also parts of the control hierarchies. In addition, Tarwaka (2010) claimed that the availability of human resources determines the effectiveness of supervision, training, and good and safe working procedures.

\section{Factor Analysis between Unsafe Actions and Occupational Accidents}

The most common unsafe actions, besides not wearing Personal Protective Equipment (PPE), were the improper way of wearing PPE and joking at work. These actions can happen due to the lack of supervision from the management section to the workers when doing their work.

From the research regarding the unsafe actions performed by the workers at PT X, the observation results disclosed that almost half of the respondents $(47.4 \%)$ performed low in unsafe actions. I addition, $52.6 \%$ of the workers carried out moderate unsafe actions.

Referring to the data on occupational accidents at PT X, occupational accidents still emerge annually. The result of the field observation revealed that there were some workers who still carried out unsafe actions when completing their works, such as the hands wedged by the spinning equipment. Ten out of 19 respondents were discovered to perform moderate category of unsafe actions. Therefore, it can be stated that unsafe actions carried out by the workers were the most influential actions in the emergence of occupational accidents at PT X.

\section{CONCLUSION}

Based on the study conducted at PT X regarding the factors of occupational accidents, it can be concluded that the knowledge factor was one of the tolerable causes of the occupational accidents, since the majority of the workers, $57.9 \%$, had already acquired good knowledge.

Other than that, the training factor also took place as one of the tolerable causes of the occupational accidents, providing the greater part of the workers, $73.7 \%$, agreed if the trainings provided by the company were good.

Furthermore, the supervision factor was also discovered as one of the tolerable causes of the occupational accidents since almost all of the workers, $78.9 \%$, claimed that the supervision carried out by the company was already good.

Last, unsafe actions were found on more than half of the workers, 52.6\%, performing moderate unsafe actions. This indicated that unsafe actions had a big contribution to the emergence of occupational accidents at PT X. 


\section{REFERENCES}

Abiszah, I. (2014) Factors Associated with the Unsafe Action of Pertamina Petrochina Workers in East Java. Undergraduate Thesis. Surabaya: Faculty of Public Health Universitas Airlangga.

Bird, J., Frank, E. and Germain, L. G. (1990) Practical Loss Control Leadership. Georgia: Loganville.

Burhani, R. (2010) Indonesia Lack of Accident Advisory Doctors. Jakarta: Antara News.Com.

Government Regulation (2012) Number 50 of 2012. About Management System of Occupational Safety and Health. Jakarta: Government Regulation.

Kurniawati, G. (2014) actor Analysis Relating to Unsafe Actions on Workers in the Assembly Process PT. PAL Indonesia. Undergraduate Thesis. Surabaya: Faculty of Public Health Universitas Airlangaa.

Lestari, P. A. and Sriathi, A. A. A. (2013) 'The Influence of Job Training, Physical Working Environment as well as the Motivation of the Employees Work Productivity in PT. Taspen (Persero) Denpasar Branch Offices', E-Jurnal Manajemen Universitas Udayana, 2(9), pp. 1071-1084.

Ministry of Health Republic of Indonesia (2014) 1 Worker in the World Died Every 15 Seconds Because of Work Accidents. Jakarta: Ministry of Health Republic of Indonesia.

Pratama, A. K. (2015) 'The Relationship between the Characteristics of Workers to Unsafe Action in Stevedor at PT. Terminal Petikemas Surabaya', The Indonesian Journal of Occupational Safety and Health, 4(1), pp. 64-73.

Pratiwi, O. R. and Hidayat, S. (2014) 'Analysis of Individual Characteristic Factors Related to Unsafe Action on Labor in Steel Construction Companies', The Indonesian Jiurnal of Occupational Safety and Health, 3(2), pp. 182-191.

President of the Republic of Indonesia (1970) Law Number 1 of 1970 about Occupational Safety. Jakarta: President of the Republic of Indonesia.

President of the Republic of Indonesia (1992) Law of the Republic of Indonesia Number 3 of 1992 concerning Labor Social Guarantee. Jakarta: President of the Republic of Indonesia.

Raharjo, N. K. (2013) Factors Associated with Happy Behavior in Work Accident Prevention Efforts in Unit I of PT Bangun Sarana Baja Gresik. Undergraduate Thesis. Surabaya: Faculty of Public Health Universitas Airlangga.

Riyadina, W. (2007) 'Occupational Accident and Injury on Industrial Workers in Jakarta Pulo Gadung Industrial Estate', Makara Kesehatan, 11(1), pp. 25-31.

Tarwaka (2010) Industrial Ergonomics: Basics of Ergonomics Knowledge and Applications at Work. Surakarta: UNIBA Press. 